\title{
Vaskulitis pada Lupus Eritematosus Sistemik
}

\author{
Zikry Aulia Hidayat ${ }^{1}$, Raveinal ${ }^{2}$
}

Abstrak

Lupus Eritematosus Sistemik (LES) merupakan penyakit autoimun kompleks yang menyerang berbagai sistem tubuh. Salah satu manifestasi LES adalah vaskulitis, yaitu inflamasi pada dinding pembuluh darah. Vaskulitis sekunder akibat LES terjadi pada beberapa pasien LES dengan gambaran yang bervariasi. Gambaran vaskulitis yang tersering pada LES adalah vaskulitis kutaneus. Dilaporkan seorang perempuan 26 tahun yang telah dikenal dengan LES, datang dengan keluhan bintik-bintik merah di kedua tungkai dan lengan yang tidak gatal dan tidak nyeri. Dilakukan biopsi pada lesi kulit dengan hasil tampak pada jaringan kulit dengan epidermis yang mengalami atrofi, hyperkeratosis, ketotik plague, terdapat daerah dengan penebalan membrana basalis. Dibawah dermis tampak sebukan sel radang perivasikuler, terdapat limfosit dan beberapa leukosit PMN. Gambaran tersebut sesuai dengan gambaran discoid lupus erythematosus dan vaskulitis. Discoid lupus erythematosus merupakan salah satu bentuk dari lupus eritematosus kutaneus dan merupakan bentuk yang tersering. Pada kasus ini vaskulitis muncul menunjukkan kambuh atau aktifnya penyakit LES yang telah diderita pasien selama 2 tahun. Hal tersebut ditunjukkan dengan jumlah skor MEX SLEDAI 6 dan skor SLEDAI 12. Pasien diberikan terapi dengan metil prednisolon intravena $2 \times 125 \mathrm{mg}$ selama 3 hari serta hidroksiklorokuin $1 \times 200 \mathrm{mg}$ per oral. Respon yang baik terlihat pada hari rawatan keenam dengan berkurangnya manifestasi vaskulitis secara signifikan.

Kata kunci: lupus eritematosus sistemik, vaskulitis

\begin{abstract}
Systemic lupus erythematosus (SLE) is a complex autoimmune disease involving many systems in one's body. One of SLE manifestations is vasculitis, an inflammation of the vessel wall. Secondary vasculitis caused by SLE happened in few SLE patients with various manifestations. The most common SLE vasculitis is cutaneous vasculitis. It has been reported a female patient (26 years old) who was known with SLE, with red spots on both her legs and arms without feeling itchy or painful. Skin biopsy was done to the patient and the result was an appearance in skin tissue with the atrophic epidermis, hyperkeratosis, ketotic plague, thickening area of membrana basalis. In dermis underneath, was distributed inflammation cells perivascular, with lymphocyte and numerous PMN leukocyte. This appearance corresponds with discoid lupus erythematosus and vasculitis. Discoid lupus erythematosus is one most common cutaneous lupus erythematosus. In this case, the occurrence of vasculitis demonstrated an active disease of SLE. Disease activity was assessed with MEX SLEDAI and SLEDAI scores, which are 6 and 12 consecutively. The patient was given intravenous methylprednisolone $125 \mathrm{mg}$ twice a day for 3 days and oral hydroxychloroquine $200 \mathrm{mg}$ once daily. A good response was found in the sixth day with significant improvement of her skin lesions.
\end{abstract}

Keywords: systemic lupus erythematosus, vasculitis

Affiliasi penulis: ${ }^{1}$ Program Studi IImu Penyakit Dalam, Fakultas Kedokteran, Universitas Andalas, Padang. ${ }^{2}$ Bagian IImu Penyakit Dalam, Fakultas Kedokteran, Universitas Andalas, Padang Korespondensi: Zikry Aulia, Email: zikryaulia@gmail.com Telp: 085263750109

\section{PENDAHULUAN}

Lupus Eritematosus Sistemik (LES) merupakan penyakit autoimun kompleks yang menyerang berbagai sistem tubuh. Faktor genetik dan lingkungan diketahui berperan dalam patogenesis penyakit ini. LES memiliki manifestasi klinis, kelainan imunologi 
dan laboratorium, perjalanan penyakit, serta akibat penyakit yang beragam. Manifestasi klinis pada kulit, sendi, ginjal, dan sistem organ lainnya tidak selalu muncul bersamaan, dan dapat berkembang seiring perjalanan penyakit. ${ }^{1}$

Insiden dan prevalensi LES tertinggi ditemukan di Amerika Utara sebesar 23,2/100.000 penduduk/tahun dan 241/100.000 penduduk. Data poliklinik di beberapa rumah sakit di Indonesia menunjukkan adanya peningkatan kunjungan pasien LES yaitu 17,9$27,2 \%$ (tahun 2015), 18,7-31,5\% (tahun 2016), dan 30,3-58\% (tahun 2017). Rasio perempuan dan laki-laki adalah 15:1 hingga 22:1. Rentang usia tertinggi 21-30 tahun. ${ }^{1}$ Insiden LES juga ditemukan lebih tinggi pada ras Afrika, Asia dan Hispanik dibandingkan Kaukasia, Kanada dan Spanyol. ${ }^{2}$

Lupus eritematosus sistemik merupakan penyakit autoimun kompleks yang ditandai adanya autoantibodi terhadap inti sel dan melibatkan banyak sistem organ dalam tubuh. Salah satu manifestasinya pada kulit adalah vaskulitis, yang terjadi pada $8-11 \%$ pasien LES. ${ }^{3}$

Vaskulitis adalah inflamasi pada dinding pembuluh darah, yang dapat berupa vaskulitis primer atau sekunder akibat penyakit yang mendasari. ${ }^{4}$ Vaskulopati dan aktivasi endotel dapat merupakan patogenesis yang penting pada LES, vaskulitis yang ditunjukkan dengan bukti histologi, arteriografi dan tampilan klinis yang khas masih jarang terjadi. ${ }^{5}$

Vaskulitis pada LES umumnya berupa vaskulitis kutaneus yang respon terhadap pemberian kortikosteroid. Bentuk lain vaskulitis yaitu vaskulitis viseral, vaskulitis pada pembuluh darah besar, dan vaskulitis mesenterikal. ${ }^{6}$

\section{KASUS}

Seorang pasien perempuan berusia 26 tahun dirawat dengan keluhan munculnya bintik-bintik merah di kedua tungkai sejak dua minggu sebelum masuk rumah sakit. Bintik merah tersebut muncul pertama kali pada tungkai kanan, lalu juga muncul di tungkai kiri dan meluas ke paha serta juga muncul di kedua lengan. Pasien tidak mengeluh gatal ataupun nyeri pada bintik-bintik merah tersebut. Pasien ini sudah dikenal menderita LES sejak 2 tahun sebelumnya dan mengonsumsi metil prednisolon $1 \times 4 \mathrm{mg}$, warfarin $1 \times 1$ $\mathrm{mg}$, osetocal $1 \times 1000 \mathrm{mg}$. Saat ini pasien masih mengeluhkan nyeri sendi, serta terdapat kemerahan pada kedua pipi yang meningkat apabila terkena sinar matahari. Tidak didapatkan demam, sariawan, ataupun penurunan berat badan.

Pasien datang dengan keadaan umum sedang dan kesadaran composmentis cooperative, tekanan darah 110/60 mmHg, nadi $98 \mathrm{x} /$ menit, nafas 18 $\mathrm{x} /$ menit, suhu $36,8^{\circ} \mathrm{C}$. Pada pemeriksaan fisik umum, pemeriksaan paru, jantung, dan abdomen dalam batas normal. Pada kulit ditemukan ptekie serta purpura yang dapat dipalpasi (Gambar 1 dan 2). Pada pemeriksaan sendi, terdapat pembengkakan pada sendi elbow bilateral dan pergelangan kaki yang disertai nyeri.

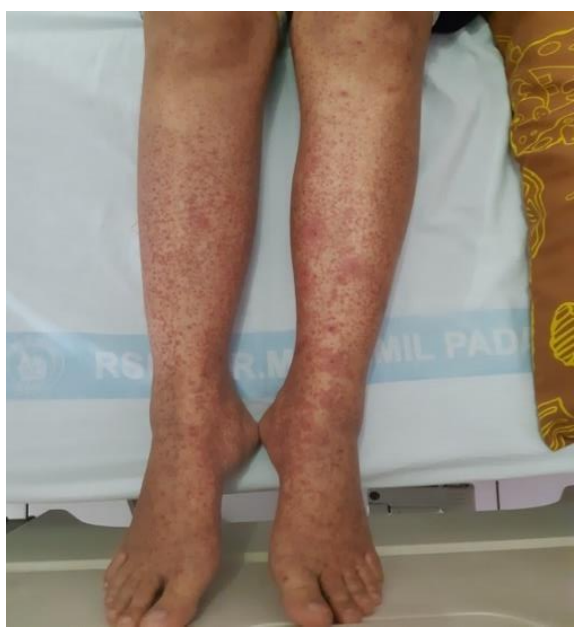

Gambar 1. Palpable purpura pada kedua tungkai

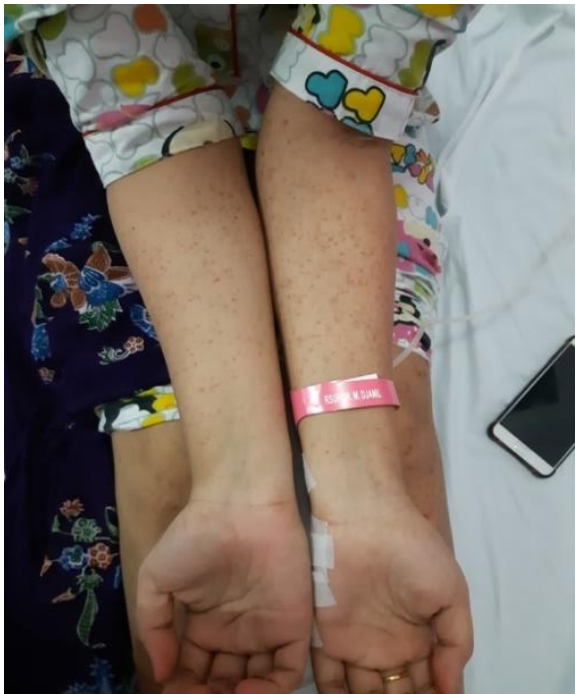

Gambar 2. Palpable purpura pada kedua lengan 
Hasil pemeriksaan laboratorium didapatkan kadar hemoglobin 11,6 gr/dl, leukosit $6.120 / \mathrm{mm}^{3}$, hematokrit $35 \%$, trombosit $302.000 / \mathrm{mm}^{3}$, LED 7 $\mathrm{mm} / \mathrm{jam}$, hitung jenis leukosit 0/1/2/65/32/0. Fungsi ginjal, hepar dan elektrolit dalam batas normal. Pemeriksaan D-Dimer menunjukkan peningkatan yaitu 7.038,1 ng/ml. Hasil pemeriksaan urin dan feses dalam batas normal.

Aktivitas penyakit dinilai dengan skor MEXSLEDAI yang didapatkan skor 6 atau LES derajat sedang, serta skor SLEDAl dengan total 12 yang menunjukkan penyakit yang kambuh/aktif. Pasien kemudian diberikan terapi injeksi metil prednisolon dengan dosis $125 \mathrm{mg} 2$ kali sehari selama 3 hari, hidroksiklorokuin 1x200 mg per oral serta warfarin 1×3 mg per oral.

Pada pasien dilakukan biopsi kulit dengan gambaran tampak pada jaringan kulit dengan epidermis yang mengalami atrofi, hyperkeratosis, ketotik plague, terdapat daerah dengan penebalan membrane basalis. Di bawahnya dermis tampak sebukan sel-sel radang perivasikuler, terdapat limfosit dan beberapa leukosit PMN. Gambaran tersebut dapat ditemukan pada discoid lupus erythemathosus dan vaskulitis. Hasil biopsi ditunjukkan pada gambar 3.

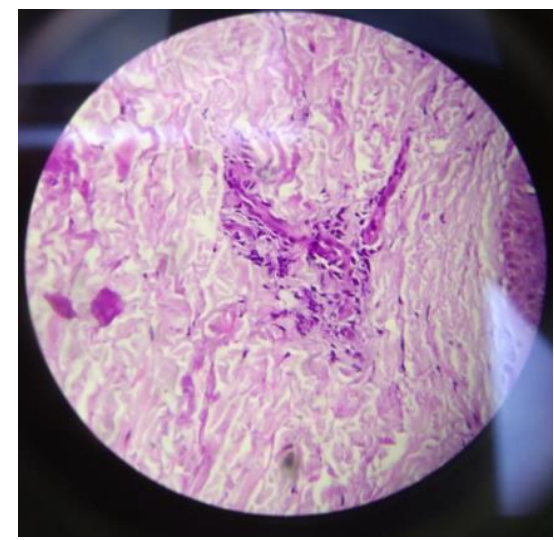

Gambar 3. Hasil biopsi kulit menunjukkan sebukan sel radang perivasikuler

Setelah 6 hari perawatan pasien mengalami perbaikan dan tampak dengan berkurangnya lesi pada kedua tungkai dan lengan (gambar 4 dan 5). Dosis metil prednisolon diturunkan pada hari ke-4 menjadi 2x62,5 mg dan pasien dipulangkan dengan dosis metil prednisolon $2 \times 8 \mathrm{mg}$.

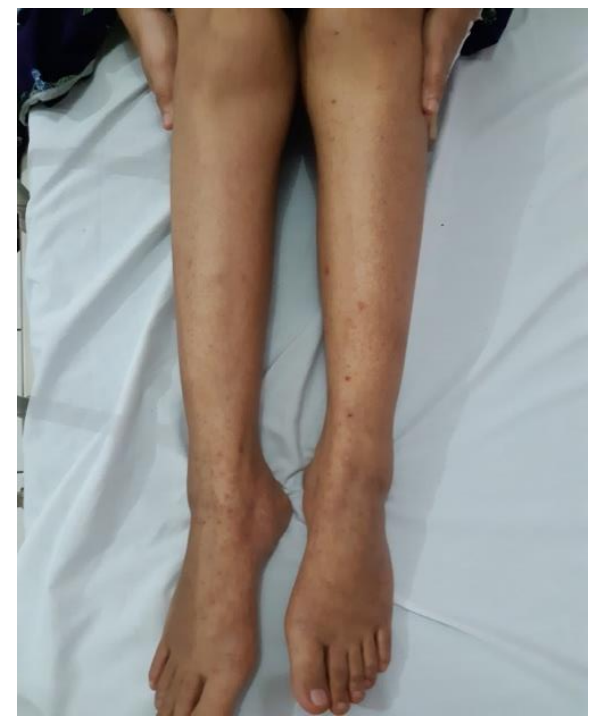

Gambar 4. Perbaikan lesi pada kedua tungkai

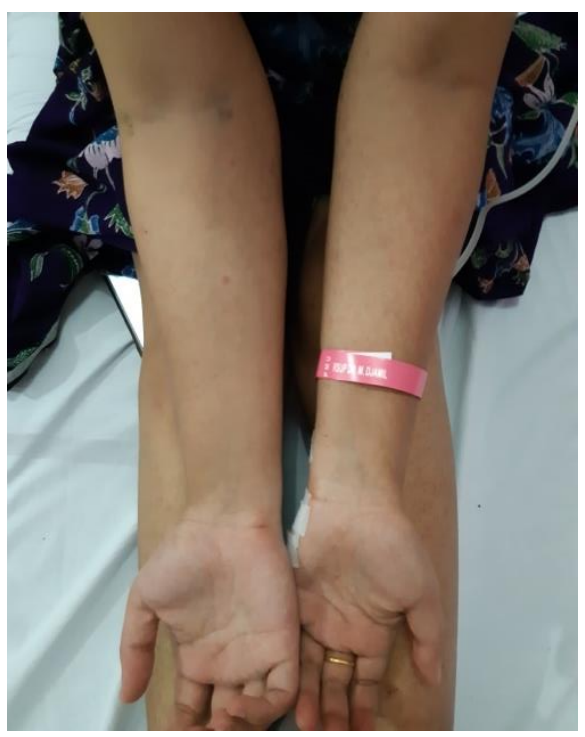

Gambar 5. Perbaikan lesi pada kedua lengan

\section{PEMBAHASAN}

Dilaporkan seorang pasien perempuan usia 26 tahun yang dirawat di Bangsal Penyakit Dalam RSUP Dr M Djamil dengan diagnosis Lupus Eritematosus Sistemik aktif, Vaskulitis dan High risk thrombosis. Selama 2 tahun pasien kontrol rawat jalan ke poliklinik Alergi dan Imunologi RSUP Dr M Djamil Padang dan telah mendapat terapi metil prednisolon dan warfarin.

Gambaran bintik-bintik merah pada kedua tungkai dan lengan yang tidak disertai gatal atau nyeri pada pasien dicurigai merupakan vaskulitis. Vaskulitis ditandai dengan adanya infiltrasi sel inflamasi dan diikuti oleh nekrosis dinding pembuluh darah merupakan salah satu perjalanan penyakit LES. $^{7}$ Proses inflamasi pada pembuluh darah dapat muncul 
dalam banyak bentuk klinis tergantung pada ukuran pembuluh darah yang dikenai dan lokasi yang terlibat. Pembuluh darah yang terkena dapat arteri atau vena dengan berbagai ukuran, dengan penyebab primer atau sekunder akibat penyakit lain seperti infeksi, penyakit kolagen, keganasan atau akibat obat. ${ }^{8}$ Pada pasien ini kemungkinan inflamasi terjadi di kulit dan mengenai pembuluh darah kecil.

Vaskulitis terjadi pada $8-11 \%$ pasien LES, paling sering terjadi pada kulit. ${ }^{3}$ Pada suatu penelitian pada 670 pasien LES, ditemukan 76 pasien dengan vaskulitis, dimana $89 \%$ vaskulitis pada kulit dan $11 \%$ vaskulitis viseral. Pada penelitian pada 670 pasien dengan LES tahun 1980 hingga 2004 di Barcelona, ditemukan kejadian vaskulitis sebanyak $11 \%$, dan kebanyakan kasusnya (89\%) merupakan vaskulitis kutaneus. Secara histologi dari 45 pasien, ditemukan leukocytoclastic vasculitis pada 29 pasien dan 10 didapatkan necrotizing vasculitis. ${ }^{9}$

Vaskulitis kutaneus pada LES dapat muncul dalam bentuk lesi lupus nonspesifik seperti purpura, urtikaria, dan lesi ekstremitas, berupa lesi limfositik atau leukocytoclastic. Vaskulitis pada pembuluh darah kecil tersering pada pasien LES adalah Leucocytoclastic vasculitis (LCV), muncul dalam bentuk ptekie dan purpura yang teraba. Namun sebelum menghubungkan LCV dengan LES, penyebab LCV lain harus disingkirkan, seperti infeksi dan obat-obatan. ${ }^{10}$

Pada pasien ini, adanya vaskulitis pada LES dibuktikan dengan hasil biopsi kulit yang tampak epidermis yang mengalami atrofi, hyperkeratosis, ketotik plague, terdapat daerah dengan penebalan membrane basalis. Di bawah dermis tampak sebukan sel-sel radang perivasikuler, terdapat limfosit dan beberapa leukosit PMN. Gambaran ini dapat ditemukan pada discoid lupus erythematosus dan vaskulitis.

Discoid lupus erythematosus (DLE) merupakan bentuk lupus eritematosus kutaneus yang paling sering. Sekitar 5-10\% pasien LES memiliki DLE pada presentasi penyakitnya. Usia tersering yang memiliki DLE adalah antara 20-40 tahun baik laki-laki atau wanita. Namun DLE lebih sering ditemukan di wajah, kulit kepala, dan telinga. Pasien dengan lesi DLE di atas leher disebut DLE terlokalisir, sedangkan lesi hingga di bawah leher merupakan DLE generalisata. ${ }^{10}$

Vaskulitis kutaneus pada LES dapat muncul dalam bentuk lesi lupus nonspesifik seperti purpura, urtikaria, dan lesi ekstremitas, berupa lesi limfositik atau leukocytoclastic. Vaskulitis pada pembuluh darah kecil tersering pada pasien LES adalah Leucocytoclastic vasculitis (LCV), yang muncul dalam bentuk ptekie dan purpura yang teraba. Ptekie dan purpura yang teraba pada LCV memiliki tempat predileksi yaitu kedua ekstremitas, seperti yang muncul pada pasien dalam kasus ini. Sebelum menghubungkan LCV dengan LES, penyebab LCV lain harus disingkirkan, seperti infeksi dan obatobatan. LCV juga harus dibedakan dengan vaskulitis urtikaria yang juga mengenai pembuluh darah kecil, dengan gambaran lesi seperti sarang lebah yang nyeri yang muncul minimal selama 24 jam dan kemudian menyisakan hiperpigmentasi post-inflamasi dengan tampilan patologi seperti LCV. ${ }^{10}$

Pasien yang sudah dikenal menderita LES perlu dilakukan pemantauan aktivitas peyakit, keterlibatan dan kerusakan organ, efek samping dan toksisitas obat, penyakit komorbid serta kualitas hidup. Perjalanan LES sangat fluktuatif yang ditandai dengan periode kekambuhan dan remisi. Setiap kekambuhan perlu dideteksi dan ditatalaksana dengan cepat dan tepat untuk mencegah komplikasi yang lebih buruk. ${ }^{11}$

Instrumen yang dapat digunakan untuk pemantauan aktivitas penyakit LES adalah SLEDAI dan MEX-SLEDAI. Pada pasien didapatkan nilai SLEDAI 12 (kambuh/aktif) dan MEX-SLEDAI 6 yang menunjukkan suatu LES derajat sedang. Pasien LES rentan mengalami kekambuhan, bahkan dengan kepatuhan pengobatan. Kekambuhan ini ditandai dengan memburuknya gejala fisik dari peradangan dan kerusakan organ. Kekambuhan dapat melibatkan organ yang sudah terkena LES atau kondisi baru yang sebelumnya belum terpengaruh. ${ }^{12}$

Flare atau kekambuhan penyakit sering terjadi tanpa sebab yang jelas, dapat terjadi karna penumpukan autoimunitas bawaan yang progresif. ${ }^{13}$ Kekambuhan juga dapat dipengaruhi oleh faktor lingkungan, seperti paparan sinar UV, infeksi, hormon tertentu, dan obat-obatan yang dapat mengaktifkan 
sistem imun bawaan dan adaptif yang mengakibatkan peradangan, efek sitotoksik, serta munculnya gejala klinis. ${ }^{14}$

Pasien mengalami LES derajat sedang (SLEDAI 6-12 atau MEX-SLEDAI 6-9) sehingga diperlukan pemberian kortikostreoid berupa metilprednisolon IV dilanjutkan kortikosteroid oral. ${ }^{15}$ Pengontrolan aktivitas penyakit, kortikosteroid dapat diberikan bersama dengan anti malaria, di mana penggunaan obat anti malaria sebagai steroid-sparing agent dapat meningkatkan kesintasan dan remisi, penurunan aktivitas penyakit dan infeksi. Pemberian antimalaria perlu dipertimbangkan untuk semua pasien LES, dengan memperhatikan efek samping dan komorbiditas pasien. Obat antimalaria yang sering digunakan adalah hidroksiklorokuin dengan dosis pemberian 200-400 $\mathrm{mg} / \mathrm{hari}$ dan maksimal 6,5 mg/kgBB/hari. ${ }^{16}$ Hidroksiklorokuin memiliki konsentrasi pada epidermis 110 hingga 200 kali lebih banyak dibandingkan dalam plasma sehingga diharapkan efektif dalam tatalaksana vaskulitis kutaneus. Casian et al (2016), pada 26 pasien dengan vaskulitis yang mendapat terapi hidroksiklorokuin dan kortikosteroid, dilaporkan adanya perbaikan gejala, terutama perbaikan pada nyeri sendi, kelelahan, dan ruam kulit. Vaskulitis relaps yang jarang dengan penurunan dosis kortikosteroid. Hidroksiklorokuin secara umum dapat ditoleransi dengan baik. ${ }^{17}$

Selama fase aktif dari penyakit inflamasi, terjadi kerusakan dinding pembuluh darah yang diperantai oleh leukosit dan menyebabkan vaskulitis. Kerusakan dari pembuluh darah tersebut mengaktifkan kaskade pembekuan, pembentukan trombus dan lepasnya Ddimer ke dalam aliran darah. Pada penelitian sebelumnya telah diketahui adanya peningkatan risiko untuk DVT pada pasien dengan vaskulitis. Pada laporan kasus yang dilakukan oleh Kirchhoff et al, ditemukan adanya hubungan antara inflamasi, peningkatan CRP, kerusakan vaskular dan peningkatan D-dimer. Nilai D-dimer dapat digunakan sebagai penanda inflamasi karena nilainya tidak dipengaruhi oleh konsumsi imunosupresif, dan secara langsung dapat menggambarkan inflamasi vaskular, aktivasi kaskade koagulasi dan fibrinolisis. ${ }^{18}$
Lupus eritematosus kutaneus merupakan faktor risiko kuat terjadinya trombosis. Hal ini mungkin disebabkan adanya peningkatan aktivitas inflamasi yang menyebakan status prokoagulan sehingga mempermudah terjadinya trombosis. ${ }^{19}$

Pada pasien juga terjadi peningkatan D-Dimer, sehingga pasien mempunyai risiko untuk mengalami trombosis. Trombosis pada pasien LES dihubungkan dengan hasil keluaran yang lebih buruk yang meningkatkan angka morbiditas dan mortalitas serta biaya pengobatan yang lebih tinggi. Untuk itu direkomendasikan untuk memberikan profilaksis trombosis dengan antikoagulan dengan tetap memantau perkembangan komplikasi dan efek samping. ${ }^{20}$

\section{SIMPULAN}

Penatalaksanaan lesi terkait LES adalah mengurangi faktor risiko. Perlindungan dari cahaya matahari merupakan hal yang penting karena lesi terkait LES sangat mudah terpicu dan mengalami eksaserbasi akibat sinar UV. Pasien diharuskan menggunakan tabir surya saat beraktivitas keluar rumah serta memakai pakaian yang dapat melindungi diri dari cahaya matahari.

\section{DAFTAR PUSTAKA}

1. Pons-Estel GJ, Ugarte-Gil MF, Alarcon GS. Epidemiology of systemic lupus erythematosus. Expert Rev Clin Immunol. 2017;13(8):799-814.

2. Lim SS, Drenkard C. The Epidemiology of lupus. Dalam: Wallace DJ, Hahn BH, Crow MK, Isenberg DA, La Cava A, Lipsky PE, et al, editor (penyunting). Dubois' lupus erythematosus and related syndromes. Edisi ke-9. Edinburgh: Elsevier; 2019.hlm. 23-41.

3. Yazdany J, Dall'Era M. Definition and classification of lupus and lupus-related disorders. Dalam: Wallace DJ, Hahn BH, Crow MK, Isenberg DA, La Cava A, Lipsky PE, et al, editor (penyunting). Dubois' lupus erythematosus and related syndromes. Edisi ke-9. Edinburgh: Elsevier; 2019. hlm. 15-20. 
4. Hahn BH. Systemic lupus erythematosus. Dalam: Kasper DL, Fauci AS, Hauser SL, Longo D, Jameson JL, Calzo JL, editor (penyunting). Harrison's Rheumatology. Edisi ke-4. New York: McGraw Hill Education; 2017.hlm.70-85.

5. Rahman A. Vasculitis in lupus. Dalam: Tsokos GC. systemic lupus erythematosus. Boston: Elsevier; 2016.hlm.481-3.

6. Arntfield RT, Hicks CM. Systemic lupus erythematosus and the vasculitides. Dalam: Marx JA, Hockberger RS, Walls RM, Biros MH, Danzl DF, Gausche-Hill M, et al, editor (penyunting). Rosen's emergency medicine concepts and clinical practice. Edisi ke-8. Philadelphia: Elsevier; 2014. hlm.1527-42.

7. Barile-Fabris L, Cabrera MF, Garfies JA. Vasculitis in systemic lupus erytematosus. Curr Rheumatol Rep. 2014;16(9):440.

8. Sukmana N. Vaskulitis. Dalam: Setiati S, Alwi I, Sudoyo AW, Simadibrata M, Setiyohadi B, Syam AF, editor (penyunting). Buku ajar ilmu penyakit dalam. Edisi ke-6. Jakarta: Interna Publishing; 2015.hlm.519-24.

9. Radic M, Kalitema DM, Radic J. Vascular manifestations of systemic lupus erythematosus. The Journal of Medicine. 2013;71(1):10-6.

10. Chong BF, Werth VP. Skin disease in cutaneous lupus erythematosus. Dalam: Wallace DJ, Hahn $\mathrm{BH}$, Crow MK, Isenberg DA, La Cava A, Lipsky PE, et al, editor (penyunting). Dubois' lupus erythematosus and related syndromes. Edisi ke-9. Edinburgh: Elsevier; 2019.hlm.395-405.

11. Suarjana NI. Imunopatogenesis lupus eritematosus sistemik. Dalam: Setiati S, Alwi I, Sudoyo AW, Simadibrata $M$, Setiyohadi $B$, Syam AF, editor (penyunting). Buku ajar ilmu penyakit dalam. Edisi ke-6. Jakarta: Interna Publishing; 2015.hlm.333145.

12. Isenberg D, Sturgess J, Allen E, Aranow C,
Askanase A, Sang-cheol B, et al. Study of flare assessment in systemic lupus erythematosus based on paper patients. Arthritis Care \& Research. 2018;70(1):98-103.

13. Fernandez D, Kirou KA. What causes lupus flares? Curr Rheumatol Rep. 2016;18(3):14.

14. Thong B, Olsen NJ. Systemic lupus erythematosus diagnosis and management. Rheumatology. 2017; 56:i3-i13.

15. Nataraja C, Morand E. Systemic glucocorticoid therapy for SLE. Dalam: Wallace DJ, Hahn BH, Crow MK, Isenberg DA, La Cava A, Lipsky PE, et al, editor (penyunting). Dubois' lupus erythematosus and related syndromes. Edisi ke-9. Edinburgh: Elsevier; 2019.hlm. 661-7.

16. Avina-Zubieta JA, Esdaile JM. Antimalarial Medications. Dalam: Wallace DJ, Hahn BH, Crow MK, Isenberg DA, La Cava A, Lipsky PE, et al, editor (penyunting). Dubois' lupus erythematosus and related syndromes. Edisi ke-9. Edinburgh: Elsevier; 2019.hlm.650-8.

17. Casian A, Sangle S, D'cruz D. The role of hydroxychloroquine in ANCA positive and negative vasculitis. Ann Rheum Dis. 2016;75(2):1-6.

18. Kirchhof MG, Lee AY, Dutz JP. D-dimer levels as a marker of cutaneous disease activity. JAMA Dermatology. 2014;150(8): 880-4.

19. Ahlehoff O, Wu JJ, Raunso J, Kristensen SL, Khalid $U$, et al. Cutaneous lupus erythematosus and the risk of deep venous thrombosis and pulmonary embolism: A Danish nationwide cohort study. Lupus. 2017:1-5.

20. Kishore S, Jatwani S, Malhotra B, Lirette ST, Mittal V, Majithia V. Systemic lupus erythematosus is associated with a high risk of venous thromboembolism in hospitalized patients leading to poor outcomes and a higher cost: results from nationwide inpatient sample database 2003-2011. ACR Open Rheumatology. 2019;1(3):194-200. 